\title{
Children of War: Quebec's Social Policy Response to Children and Their Families
}

\author{
Sarah Fraser ${ }^{1}$, Myriam Denov ${ }^{2}$, Jaswant Guzder ${ }^{3}$, Sharon Bond ${ }^{2}$, Neil Bilotta ${ }^{2}$ \\ ${ }^{1}$ School of Psychoeducation, University of Montreal, Montreal, Canada. \\ ${ }^{2}$ School of Social Work, McGill University, Montreal, Canada. \\ ${ }^{3}$ Child Psychiatry department, Jewish General Hospital, Montreal, Canada. \\ Correspondence: Sarah Fraser, Pavillon Marie-Victorin École de psychoéducation C. P. 6128, succursale Centre-ville \\ Montréal (Québec) H3C 3J7, Canada.
}

Received: April 5, 2016

doi:10.11114/ijsss.v4i7.1644
Accepted: April 25, 2016

Available online: May 30, 2016

URL: http://dx.doi.org/10.11114/ijsss.v4i7.1644

\begin{abstract}
Canada has signed the Optional Protocol of the Convention on the Rights of the Child on the involvement of children in armed conflict that obligates signatories to ensure assistance and support to war-affected children's physical and psychological recovery as well as their social reintegration. In light of this obligation, the paper reviews the most recent policies related to immigrants and refugees of four Quebec (Canada) ministries, with particular attention to the frameworks underpinning these policies and practices in order to explore how the needs of refugee children are conceptualised and how these same conceptualisations orient the action plans. Miller and Rasmussen's (2010) psychosocial/trauma integrative model is used as a benchmark to assess whether and how policies integrate considerations from both psychosocial and trauma focused conceptual models. The analysis suggests that all four ministries adopt a psychosocial focus but that none directly mention the impact of war, potential trauma or pre-migratory experiences on children's reintegration or resettlement. There seems to be a divide and a lack of coherence in the goals and underlying philosophies of the action plans of the different ministries, most likely in part related to their differences in mandate. Indeed, the Ministry of Health and Social Services emphasizes individual and family wellbeing, while the Ministry of Education prioritizes citizenship and the development of Quebec. Potential implications of these policy orientations for children having been exposed to war living in the Quebec context are discussed.
\end{abstract}

Keywords: refugee children, social policies, trauma, psychosocial, Quebec

\section{Introduction}

Millions of children are caught up in the maelstrom of armed conflict with the sequela of casualties including death, severe injury, and a generation of child orphans often permanently separated from families (UNICEF, 2009). It has been estimated that $75 \%$ of the world's child population -1.5 billion children - live in the 42 conflict-affected countries, and an estimated 13.7 million children are internally displaced as a result of war (UN, 2010). While wars may occur beyond Canadian borders, each year thousands of children enter Canada, fleeing from war-afflicted regions (Stewart, 2011). In Quebec, between 2003 and 2012, 7 of the top 10 source countries for accepted refugees were war-affected nations, representing nearly 27,000 people (Ministère de l'Immigration et des Communautés Culturelles (MICC), 2015). Examples of source countries include: Democratic Republic of Congo, Syria, Colombia, Burundi, and India. For these children, war-related experiences are typically accompanied by poverty, discrimination, isolation, and challenges in school (Denov \& Bryan, 2014; Denov \& Bryan, 2012) .

Similar to many countries, Canada has signed the Universal Declaration of Human Rights ${ }^{1}$, and the International Convention on Economic, Social and Cultural Rights ${ }^{2}$. It has also signed the Optional Protocol of the Convention on the

\footnotetext{
1 The Declaration includes 30 articles that were adopted by the United Nations General Assembly in 1948 following. The document can be found on : www.ohchr.org/EN/UDHR/Documents/UDHR_Translations/eng.pdf

2 Adopted in 1966 by the General Assembly of the United Nations. Accessible at: www.ohchr.org/EN/ProfessionalInterest/Pages/CESCR.aspx
} 
Rights of the Child ${ }^{3}$ on the involvement of children in armed conflict that states, "Parties shall, when necessary, accord to such persons all appropriate assistance for their physical and psychological recovery and their social reintegration" (UNCRC, article 38 and article 39). As such, Canada has an obligation to provide long-term support and assistance to children affected by war.

Our research group brings together 10 professors from 5 disciplines: social work, transcultural psychiatry, education, psychology, and applied human sciences. In addition to the professors, there are 7 graduate students from diverse disciplines. As clinicians and researchers living in Quebec and specialised in fields of childhood exposure to war, immigrant and refugee mental health, and family wellbeing we are particularly interested in the experiences of refugee youth having experienced war and living in Quebec, as well as the circumstances that influence such experiences. The professors and students are integrated into four research axes which explore the following: 1) Quebec policies around services for immigrant and refugee youth 2) experiences of war-affected refugee youth living in Quebec (Blanchet \& Denov, 2015) 3) arts-based methodologies and ethics regarding research approaches when working with youth (Akesson, et al., 2014) and 4) a youth forum that also acts as an advisor group to the research team. This subgroup is led by refugee youth from Sierra Leone, Colombia, and Rwanda. The large team met approximately 3-4 times a year over three years to reflect on each group's work, and the integration between axes. The following paper focuses primarily on the first axis: the review of Quebec policies all the meanwhile integrating voices of refugee youth as documented in the qualitative study of axis 2 (Blanchet \& Denov, 2015).

The article describes the findings of this policy study, findings that were generated by the following question: How do Quebec policies integrate psychosocial and trauma related experiences and needs of children and families exposed to war? As will be discussed below, Miller and Rasmusen's (2010) integrative model is used as a benchmark for assessing the policies. This model recognises the impact of both pre-migratory and post-migratory experiences on trauma related symptoms, as well as on psychosocial determinants of wellbeing (see table 1).

Table 1. An "Integrated" model that takes into consideration the direct effects of war, the effects of war mediated by psychosocial stressors, and the impacts of other psychosocial stressors on the health and wellbeing of children.

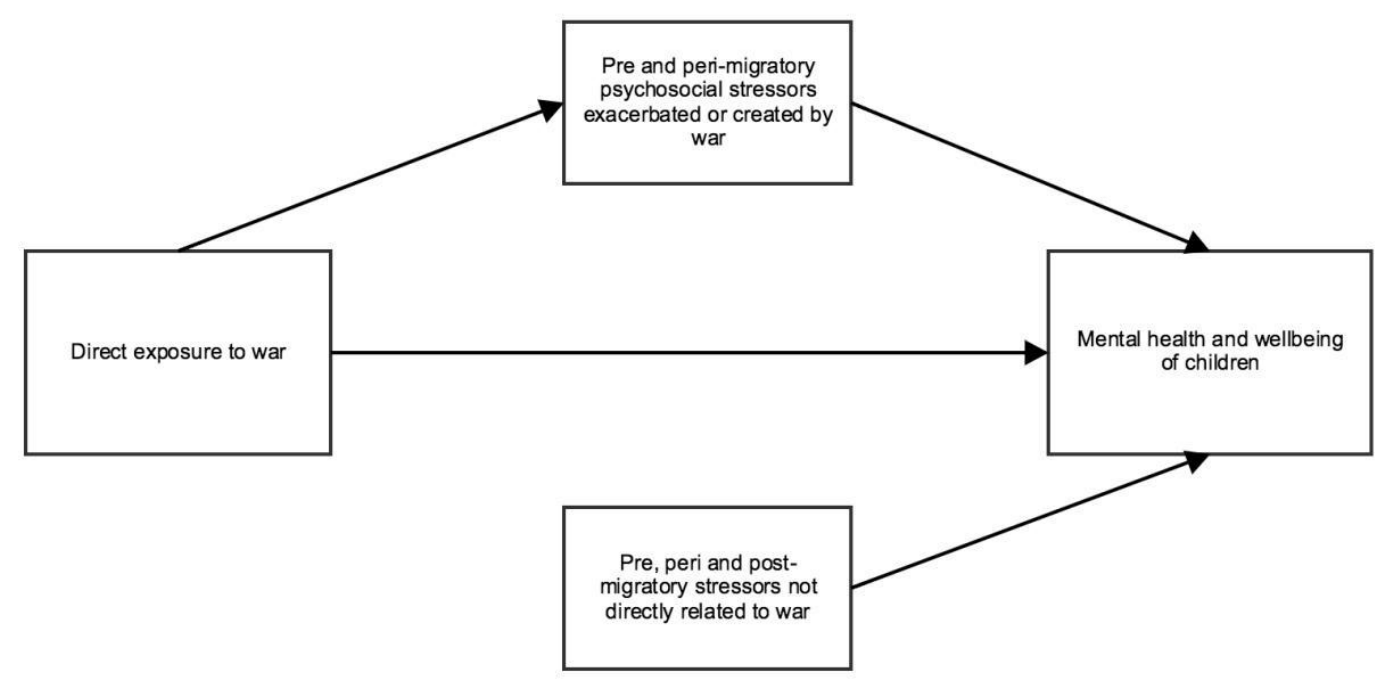

Modified version of the diagram presented in Miller \& Rasmussen, 2010.

In this paper we explore the debates concerning the various approaches to understanding and addressing the mental health needs of war affected children and their families, both during and following armed conflict. In light of these needs, we examine how and whether Quebec social policies address the trauma-related and psychosocial related realities of refugee children or adolescents who have experienced war. We also highlight the implications of these policies for clinical and help-seeking experiences of these children by integrating data published by members of our research team (Denov \& Blanchet-Cohen, 2014; Blanchet-Cohen \& Denov, 2015).

\footnotetext{
${ }^{3}$ Adopted in 2000 by resolution of the General Assembly of the United Nations. Accessible at : ohchr.org/EN/ProfessionalInterest/Pages/OPACCRC.aspx
} 


\subsection{Refugee Children Exposed to Armed Conflict: Understanding the Complexities of War and Migration}

Research suggests that children who have been exposed to conflict and have immigrated to the Global North have unique health and social needs when integrating in their host country (Fazel, Reed, Panter-Brick, \& Stein, 2012; Rousseau, 1995). As will be presented in the literature review below, refugee children and youth who come to Quebec have greatly diversified experiences that may occur during pre, peri and post migratory periods.

\subsubsection{Pre-Migration Realities: The Effects of War on Children}

Immediate experiences of war can have devastating effects on children. Young refugees may suffer from serious trauma, from direct or indirect forms of organized violence or torture that occur in their countries of origin (Denov \& Akesson, 2013; Guyon, 2011; Kirmayer et al., 2011; Vizek-Vidović, Kuterovac-Jagodic \& Lidija Arambašić, 2000). Children exposed to armed conflict may not only witness or participate in violence, but also experience the wider implications of war and conflict in contexts where social and economic systems are ruptured, and organised violence is often institutionalised (Somasundaram, 1996; Thompson, 1999). In such environments, children may experience profound poverty, displacement, social oppression, and persecution. Children having experienced conflict or war often have to cope with the loss of their cultural and social environment, as well as the loss and death of family members and friends (Derluyn \& Broekaert, 2007). These secondary consequences of war are also associated with psychological wellbeing including emotional and behavioural impacts (Thabet, Karim \& Vostanis, 2006). In their quantitative study conducted with children having experienced war, Husain and colleagues (2008) found strong associations between exposure to war trauma, ADHD-like symptoms and PTSD symptoms among Bosnian children. Post-traumatic Stress Disorder (PTSD) for refugees is roughly ten times the rates of the host country's population (Fazel et al. 2012). In studies conducted in Palestine (Thabet \&Vostanis, 1999) and Sarajevo (Husain, Allwood, \& Bell 2008), 41\% of children reported moderate/severe symptoms of PTSD. Moreover, war exposure and active participation in war can also have major impacts on individual and social identity. Indeed, research has explored how experiences of political violence and war influence cognitive schemata of self, ethnic belonging and the social-cognitive representations of interpersonal relationships. These are especially common among youth during periods of identity development and consolidation. The various impacts of war can, in turn, influence one's integration within a host society (Macksoud et al, 1993). It has been argued that immigrant and refugee children affected by war often experience precarious identities where "feeling different" is, in fact, the norm (Nwosu \& Barnes, 2014).

\subsubsection{War-Induced Migration}

Migration is often a long and complex journey typically involving several countries in a family's passage to Canada. Children may immigrate with their families or as unaccompanied minors. Family members may migrate in phases, with subsequent displacements, separations and losses. In addition, crossing a border does not always imply 'safety.' Children may have to live temporarily in refugee settlements that are often deprived of certain of basic resources and security. Children in these contexts may experience a variety of daily stressors, poverty, unsanitary environments, and or various forms of violence, contributing to mental health vulnerabilities such as PTSD, anxiety and depression, feeling of marginalization and loss of self-esteem (Guyon, 2011; Kirmayer et al., 2011; Pacione, Measham, \& Rousseau, 2013).

Arriving at the "final destination" can actually be seen as the beginning of a long journey. Asylum seekers may arrive without refugee status and await months if not years to obtain a legal migratory status that allows them to access health and education. This 'in-between' status is often accompanied by stress, and at times distress (Kirmayer et al., 2011). Feelings of isolation, marginalization and discrimination (Burnett \& Peel, 2001; Kirmayer et al., 2011) are also commonly noted experiences lived by migrants and affecting mental health and their ability to adapt to their host country. Interestingly, among individuals having experienced war and social violence, these post-migration stressors identified above are some of the strongest predictors of mental health including depression, anxiety and PTSD (Betancourt, Agnew-Blais, Gilman, Williams, Ellis, 2010; Ellis, MacDonald, Lincoln, \& Cabral, 2008; Gorst-Unsworth \& Goldenberg, 1998; Miller et al., 2002; Steel et al., 1999).

Family structures and dynamics are deeply affected by complex socio-economic contexts where parents may not be able to speak the language of the host country, may not have regular paid work, and may have to rely on their children or other family members for translation and integration (Fantino \& Colak, 2001). These challenges to the family dynamics may in turn lead to intergenerational conflicts (Kirmayer et al., 2011). Resettlement and integration may occur at uneven levels for family members, including the particular obstacle of host language acquisition. Moreover, in schools, children may encounter discrimination and racism (Bates et al., 2005).

\subsection{Addressing the Needs of War-affected Children: Bridging the Divide}

Given the powerful pre and post-migratory realities of war-affected children, a multitude of approaches have been developed to address the complex needs of children who have experienced war (i.e. Akello, Richters \& Reis, 2006; 
Betancourt, 2008; Ertle et al., 2011; Kohrt et al., 2010; Medeiros, 2007). Miller and Rasmussen (2010) have identified an important divide within this literature. On the one hand, they suggest that some researchers will adopt a trauma-focused approach in their studies meaning that for these researchers "the critical factor is direct exposure to the violence and destruction of war- the types of potentially traumatic exposure typically assessed by war-events checklists (Miller \& Rasmussen, 2010). Trauma-focused clinical treatments are generally individualized (Greenwald, 2000), though group interventions are also possible. On the other hand, groups of researchers explore and promote psycho-social approaches that is "focused primarily on the stressful social and material conditions caused or worsened by armed conflict" including poverty, malnutrition, displacement, and destruction of social networks (Miller \& Rasmussen, 2010). Reducing the impact of stressful conditions and increasing psychosocial resources is believed to improve wellbeing while fostering war-affected children's inherent capacities to adapt after exposure to war-related violence and loss (Betancourt \& Williams, 2008; Boothby, Strang, \& Wessels, 2006).

Miller and Rasmussen (2010) offer a variety of explanations for this divide and argue that this division between advocates of trauma-focused and psychosocial approaches is unnecessary and unhelpful. In response, they propose a model that attempts to bridge trauma related and psychosocial related stressors. In their models, the factors associated with adaptation and wellbeing following exposure to war are regrouped into "direct war experiences", "daily stressors that are caused or worsened by war experiences" (acting as a mediator between experiences of war and wellbeing), and "daily stressors that are unrelated to war experiences". In organising underlying factors in such a way, both pre-migratory and post-migratory conditions can be taken into account, as are both the psychosocial stressors and the direct exposures to trauma (see table 1). This is important as recent studies suggest that pre-migratory experiences interact with post-migratory experiences, and that models promoting both healthy environments and psychological needs related to trauma are optimal (Miller \& Rasmussen, 2010; Schweitzer, Brough, Vromans \& Asic-Kobe, 2011). We use this integrative approach as a benchmark for our analysis of Quebec policies and practices and the ways in which they may impact upon the lives of war-affected refugee children and youth.

\section{An Exploration of Policies for War-affected Refugee Children in Quebec, Canada}

Policies are also illustrations of specific contexts that influence priorities and ideologies. Action plans and policies are developed within unique historical and political contexts. In this section, we discuss some of the specificities unique to the province of Quebec and that likely influence how ministerial guidelines are articulated. Moreover, these policies shed light on the ways in which the needs of children arriving from post war and post conflict regions are defined and addressed.

\subsection{Context to Quebec Immigration policies}

Quebec has made immigration part of its socio-economic development plan, with a particular interest in immigrants within the economic category (69.8 per cent). Family reunification category represent 19.4 per cent while refugee status represent 9.7\%. Approximately one in nine Quebec residents are born outside of the country compared to 20 percent from Canada and 28\% from Ontario (Verngroff, 2013). Over the past decade, various policies have been written in relation to "managing diversity." For immigrants and refugees, integration into Quebec society presents unique issues due to a variety of policies as well as to the political history of the province and its relation to Canada. While this complex history goes far beyond the scope of the paper, the following offers a brief context in which policies have been developed in Quebec.

Immigration has been at the forefront of Canadian politics for as long as Canada has been a Nation. However, since the tragedy of 9/11, migration and refugeehood have been particularly delicate topics that have nourished social and political discourses of fear and xenophobia around the world (Poynting \& Masson, 2007; Rousseau et al, 2015). Highly polarised international and national debates have emerged. The debates surrounding the 2015 federal elections were a testimony to the prominence of immigration and refugeehood in the collective concerns of Canadians. With important shifts in immigration policies witnessed over the past decade under a conservative government, Canadian citizens and mass media have paid particular attention to the parties' proposals regarding the welcoming of Syrians refugees. One particular policy that has marked Federal Prime Minister Harper's ${ }^{4}$ legacy is the abolition, without notice or consultation, of the interim federal health program in 2012. The program, which was initiated in 1957, ensured basic health services for asylum seekers. This policy change denied asylum seekers access to health services unless their medical condition is a threat to public health. These federal shifts set the table for provincial actions related to immigration and refugeehood after 2012. As will be described below, in the province of Quebec the ministry of Health and Social Services initiated an action plan meant to assess the needs and develop services for refugees and asylum

\footnotetext{
${ }^{4}$ Steven Harper, head of the Conservative Party of Canada, served as the 22nd Prime Minister of Canada between February 2006 and November 2015
} 
seekers arriving to Quebec.

The province of Quebec has a unique independence with regard to immigration policies since the signing of the Canada-Quebec accord in 1994. This accord allows the province to develop its own criteria for selection of immigrants and refugees selected abroad. However, under this accord, Canada remains in charge of the selection and processing of asylum seekers. The accord was negotiated in order to ensure the promotion of French language and the uniqueness of Quebec's cultural identity. It also set Quebec apart from Canada by its use of an intercultural model rather than multicultural model within policy (Fontaine, 1993; Guyon, 2011; Helly, 1996; Salée, 2007).

In contrast to most Canadian provinces, Quebec developed a regionalisation policy, whereby arriving refugee families are relocated to one of 13 pre-selected regions of Quebec (Guyon, 2011). This regionalization policy is meant to enhance the demographic, economic and cultural contribution of immigration throughout Quebec, presumably to promote integration and Quebec cultural exposure. Most, if not all of these regions, are largely francophone. A downfall to this approach may be the limits of mutual support of ethnic minorities via informal social networks.

\subsection{Organisation of Quebec Ministries and its policies}

Ministries are governmental organs meant to orchestrate the various institutions under their governance. Their staff develop policies that are meant to guide and promote priorities and actions. Policies incorporate and disseminate a set of values and ideologies and they can be considered as "discursive practices available for analysis of the principles, concepts and tensions involved in society" (Daiute, 2008). Although they do not necessarily portray the reality of practice, the values and objectives of policies are often enacted in practice via targeted funding. They are also generally reflected by the development of materials and activities made available in institutions and organisations.

Youth having experienced war and having immigrated to Quebec will most likely be in contact with educational institutions under the Ministry of Education (MELS); hospitals, clinics and Centre Intégré de Santé et de Services Sociaux (frontline community located health and social services) under the Ministry of Health and Social Services (MSSS), and depending on their age, daycare facilities under the Ministry of Family (MFA). Moreover, the Ministry of Immigration and Cultural Communities (MICC) offer guidelines and policies to all Ministries as related to immigration and integration. The ministerial action plans and policies will therefore influence services available to these youth.

Over the past decades, the four ministries explored in this paper have published (or co-published) a variety of policies and guidelines related to immigration, diversity and how to work with refugee populations. We conducted an exhaustive online search of all policies published by one of these four ministries since 1990 using Google search engine and the search engines of all four Ministries. Reading through the material we searched for any references to other polices or action plans. For the purpose of this paper, we focused on the more recent publication of each of the four Ministries mentioned above in order to explore the ways in which the documents refer to the comprehensive needs of refugee children having been exposed to war, and to explore how policies to come may be improved to ensure continuity and coherence in services.

2.3 Cadre de reference Accueil et integration des élèves issus de l'immigration au Québec Ministry of Education (MELS)

In 2014, Quebec's Ministry of Education (2014) published a guide on welcoming and integrating immigrant children within the school system. The guide circumscribes the difficulties of migrant children around French language acquisition and academic standing. These difficulties are explained by a variety of factors which are briefly enumerated in the report: not having French as a first language, having scholastic delays due to immigration, having disabilities, and living in difficult socio-economic contexts due to migration or pre-immigration contexts. In order to address these vulnerabilities, the guide suggests focusing on forms of support around language acquisition including French and the child's native language, as well as academic support. The guide also suggests enhancing social and scholastic integration of children by linking with the family through intervenants communautaires scolaires interculturels (ICSI) ${ }^{5}$.

Although the guide mentions that migratory experiences and re-settlement can influence academic success and French language acquisition, the document does not allude to how these experiences might impact children's ability to learn and socially integrate within the school setting. It does not discuss any potential issues related to previous exposure to trauma, armed conflict, loss and grievance, biculturalism, identity development or changes in family dynamics.

${ }^{5}$ ICSIs are interveners who work in close collaboration with schools and community organisations to support refugee children and families. 
2.4 Une passerelle vers un avenir en santé. La planification et l'organisation des services à l'intention des réfugiés et des demandeurs d'asile: évaluer le bien-être et l'état de santé physique pour mieux desservir. Ministry of Health and Social Services

In 2012, shortly after the elimination of the Federal Interim Health Program, the Ministry of Health and Social Services (MSSS) developed an action plan specifically for working with refugee and asylum seekers. The key value that underpins MSSS' action plan is "equality."

The MSSS action plan appears to be rooted in the notion that refugees can be highly vulnerable due to a variety of life experiences. The objectives of the action plan are to provide rapid access to assessment in order to evaluate the wellbeing and physical health of all refugees, to ensure services that meet their specific and complex needs. Additionally, they aim to develop networks of expertise on refugee health and wellbeing. The principles of the action plan are to provide a continuum of services, from non-specialised to hyper-specialised, based on the specific needs of the client. Finally, the policy requests that a systematic screening of all immigrants and refugees include a psychosocial assessment.

The action-plan is clearly geared towards enhancement of health and wellbeing. The document states the exploratory phase of the action-plan and the need to better assess the needs of refugees. To date, the needs are described for "people and their families" with no specific mention of needs of children or youth. Multiple pre, peri and post migratory experiences are described, however their associations with health and wellbeing are not discussed. The general approach of this document emphasizes psychosocial needs, with no discussion of potential trauma implications or direct references to war-affected children and youth.

2.5 La diversité: Une valeur ajoutée Guide pour l'élaboration d'une politique d'immigration des enfants de nouveaux arrivants et de gestion de la diversité dans les services de garde éducatifs » (Ministère de la Famille et de l'Enfance (MFA), 2013).

Following Ministry of Immigration and Cultural Communities action-plan "gestion de la diversité" (described below) the MFA developed this new guide in collaboration with the MELS. This MFA guide describes the difficulties of immigrants primarily in relation to the acquisition of French language and to the adaptation and integration to Quebec culture. Integration is defined as a long process that once achieved is assessed by the acceptance of the cultural references of the host society and suggests this as a major factor for full participation in Quebec society. The guide's objectives are to promote Quebec's values of preventing racism and discrimination, enhancing intercultural encounters, sensitizing educators to the specific realities of immigrant families while enhancing the participation of parents within the system.

The guide was written in collaboration with the MELS and clearly shares many commonalities with the MELS action plans. It is oriented towards principles of integration and interculturalism with a focus on language acquisition. There is no mention of pre-migratory or post-migratory experiences and how they may impact resettlement and integration.

2.6 "Plan d'action du gouvernement du Quebec pour l'accueil et l'intégration des personnes réfugiées sélectionnées à l'étranger, 2013-2016". (Ministry of Immigration and Cultural Communities, MICC)

After having published broad action-plans to reduce discrimination and racism towards visible minorities, and to improve integration and French language acquisition of immigrants, the MICC recently published an action-plan specifically in relation to refugees selected abroad. After consulting elected officials and organisational partners of the 13 regions that receive refugees selected abroad, the authors of the action plan report important gaps in access and pathways to services for refugees arriving in Quebec. The consultations revealed a lack of knowledge regarding both the needs and availability of services for refugees, as well as a variety of organisational and logistical barriers to offering specialised services to refugees. The objectives of the proposed action plan are to assess the current practices put in place within institutions and organisations for refugees, to assess use of services that are available to refugees, to improve governmental interventions by enhancing collaboration between institutions, to develop tools adapted to the needs of refugees and to ensure continuing education of interveners.

This action plan appears to integrate elements of both the MSSS and MELS action plans. It suggests an improved process for the evaluation of refugee's needs with regards to health and wellbeing (as in the MSSS action plan) and increasing support for refugee children with scholastic difficulties (MELS). Similar to the MELS action plan, the MICC highlights the importance for schools to work with families in such a way that families are more aware of how Quebec "scholastic culture" functions (pg 9). Children are only discussed in relation to their scholastic and linguistic needs. There is no mention of health, developmental, bicultural identity or psychosocial needs. 


\section{Discussion}

\subsection{How do policies conceptualise and position themselves with regard to the needs of children exposed to war?}

As noted earlier, Miller and Rasmussen $(2010 ; 2016)$ suggest that trauma-oriented and psychosocially oriented approaches be integrated in order to offer a complex and holistic understanding of children's needs. We therefore sought to explore whether the four policies embraced this integrative approach in their conceptualisation of needs, and whether their approaches overlapped. As illustrated in table 1, an integrative approach would take into consideration 1) direct exposure to war and any potential trauma, or psychological difficulties, associated with this exposure 2) the psychosocial stressors exacerbated by war 3) other psychosocial stressors such as those related to migration, integration, isolation, changes in family dynamics, and learning a new language.

As seen in table 2, all policies related to refugee children and families adopt psychosocial focuses with the articulated priorities being French language acquisition, social integration, reducing discrimination (MELS; MFE), and conducting psychosocial and medical assessments of needs (MICC; MSSS), all of which are psychosocial stressors un-related to direct exposure to war. None of the policies describe the potential impact of war or pre-migratory experiences on children's health, identity, social and scholastic integration, nor the impact on family systems, which are the bedrock of the child's developmental passage. Although the MSSS and the conjoint MFA/MSSS both suggest that individuals can be negatively impacted by pre-migratory experiences, it remains unclear what these experiences might be, how they influence wellbeing and integration, or how children are affected by these experiences. In fact, the MSSS does not mention children at all.

With the MELS, MFA and MICC documents, children are mainly described in relation to linguistic and scholastic needs. The focus is on integration of children within Quebec society. In the MELS, MFA/MELS, and MICC documents, diversity is integrated within a Quebec culture and French language framework.

In this sense, the policies and action-plans are not only barren of trauma related concerns, they also offer a limited psychosocial lens, one that focuses uniquely on the psychosocial stressors directly related to "integration" within the institutions. This prioritisation of language, culture and social integration is not inherently problematic, especially considering the mandate of schools and the literature in the field suggesting that wellbeing of refugees is highly dependent on their social integration, and their ability to communicate within their host society (Burnette \& Peel, 2001; Fantino \& Colak, 2008; Kirmayer, 2011; Miller \& Rasmussen, 2016). However, the ability to learn and integrate within the host society is contingent upon having the psychological availability to learn. As clearly demonstrated in existing scholarship reviewed earlier, having experienced trauma can seriously tax social, academic, and identity development.

Table 2. Comparison of four Ministerial policies

\begin{tabular}{|c|c|c|c|c|}
\hline & MELS (2014) & MSSS (2012) & MFA/MICC & MICC (2013) \\
\hline Goal & $\begin{array}{lr}\text { Integration } & \text { of } \\
\text { immigrant } & \text { children: } \\
\text { increase } & \text { French } \\
\text { acquisition, improve } \\
\text { scholastic abilities }\end{array}$ & $\begin{array}{l}\text { Provide rapid access to } \\
\text { assessment in order to } \\
\text { evaluate and improve health } \\
\text { and wellbeing of refugees }\end{array}$ & $\begin{array}{l}\text { Enhance integration of all } \\
\text { children, including new } \\
\text { immigrants. Improve } \\
\text { management of diversity } \\
\text { in a way that promotes } \\
\text { Quebec Values. } \\
\text { Prevent Racism. }\end{array}$ & $\begin{array}{l}\text { Integration of } \\
\text { selected abroad. }\end{array}$ \\
\hline \multirow[t]{4}{*}{$\begin{array}{l}\text { Contextual factors } \\
\text { that influence goals }\end{array}$} & $\begin{array}{l}\text { Decentralisation and } \\
\text { regionalisation }\end{array}$ & $\begin{array}{l}\text { Decentralisation } \\
\text { regionalisation }\end{array}$ & \multirow{4}{*}{$\begin{array}{l}\text { Increase in diversity of } \\
\text { immigrants, especially as } \\
\text { related to their countries } \\
\text { of origin }\end{array}$} & $\begin{array}{l}\text { Decentralisation } \\
\text { regionalisation }\end{array}$ \\
\hline & $\begin{array}{l}\text { More immigrants for } \\
\text { whom French in not } \\
\text { first language }\end{array}$ & $\begin{array}{l}\text { Lack of expertise in refugee } \\
\text { health outside of urban } \\
\text { centers, unequal quality of }\end{array}$ & & $\begin{array}{l}\text { Increase in diversity of } \\
\text { refugees. }\end{array}$ \\
\hline & $\begin{array}{l}\text { Quebec promotion of } \\
\text { French language }\end{array}$ & $\begin{array}{l}\text { services throughout the } \\
\text { province. }\end{array}$ & & $\begin{array}{l}\text { Difficulty in having all } 13 \\
\text { regions work together. }\end{array}$ \\
\hline & & $\begin{array}{l}\text { Lack of intercultural } \\
\text { training }\end{array}$ & & \\
\hline $\begin{array}{l}\text { Premigratory } \\
\text { experiences }\end{array}$ & $\begin{array}{l}\text { No mention } \\
\text { pre-migratory } \\
\text { experiences }\end{array}$ & $\begin{array}{l}\text { Certain Pre-migratory } \\
\text { experiences are named }\end{array}$ & $\begin{array}{l}\text { No mention of } \\
\text { pre-migratory experiences }\end{array}$ & $\begin{array}{l}\text { No mention of pre-migratory } \\
\text { experiences }\end{array}$ \\
\hline $\begin{array}{l}\text { Peri and } \\
\text { postmigratory } \\
\text { experiences }\end{array}$ & $\begin{array}{l}\text { One sentence suggests } \\
\text { that the migratory } \\
\text { experience can impact } \\
\text { scholastic integration. }\end{array}$ & $\begin{array}{l}\text { Grievance, } \\
\text { unsanitary conditions of } \\
\text { refugee camps, potential } \\
\text { health problems, exposure }\end{array}$ & $\begin{array}{l}\text { No mention of peri and } \\
\text { post-migratory } \\
\text { experiences }\end{array}$ & $\begin{array}{l}\text { Lack of knowledge of French } \\
\text { Low schooling at moment of } \\
\text { arrival } \\
\text { Scholastic difficulties. }\end{array}$ \\
\hline
\end{tabular}




\begin{tabular}{|c|c|c|c|c|}
\hline & & $\begin{array}{l}\text { to violence, loss of social } \\
\text { and cultural reference } \\
\text { points, culture choc in new } \\
\text { country, immigration status, } \\
\text { socio-economic difficulties }\end{array}$ & & $\begin{array}{l}\text { Can experience social } \\
\text { isolation }\end{array}$ \\
\hline Trauma & No mention of trauma & $\begin{array}{l}\text { "experiences lived by } \\
\text { refugees is } \\
\text { traumatising" }\end{array}$ & No mention of trauma & No mention of trauma \\
\hline Children & $\begin{array}{l}\text { Children are at the } \\
\text { center of policy. } \\
\text { Needs articulated } \\
\text { around language } \\
\text { acquisition, academic } \\
\text { integration }\end{array}$ & No reference to children & $\begin{array}{l}\text { Children are the focus of } \\
\text { the policy. Needs } \\
\text { articulated around } \\
\text { language acquisition, } \\
\text { academic integration }\end{array}$ & $\begin{array}{l}\text { The discussion around needs } \\
\text { of children is geared towards } \\
\text { scholastic and linguistic } \\
\text { integration }\end{array}$ \\
\hline
\end{tabular}

\subsection{From Policy to Experience}

In order to ground the analysis of the ministerial policies, and to explore their practical relevance, we integrate the voices of refugee youth living in Quebec, interviewed in a qualitative study undertaken in parallel to this critical analysis of policies, by members of our team. The main objective of the qualitative study (Blanchet-Cohen \& Denov, 2015) was to better understand how to offer "all appropriate assistance for their physical and psychological recovery and their social reintegration" according to the experiences and perspectives of refugee youth in Quebec who are using the institutions that are guided by the policies explored in this study. The participants were aged between 15 and 30 and came from one of the following countries Colombia, Democratic Republic of Congo, Nepal, Rwanda, Sierra Leone, Sri Lanka, Togo, and Zimbabwe. For more details on methods and results please see Denov \& Blanchet-Cohen (2014) and Blanchet-Cohen \& Denov (2015).

Within Blanchet-Cohen \& Denov's (2015) study, youth spoke of the impact of pre-migratory trauma on their ability and desire to learn. When these experiences are not taken into consideration, youth may not have the safety and availability to integrate what is being taught within the school setting.

I was able to go to school, but I did not study well as I would be before... Yeah, [the genocide] affects my studies, because, sometimes it's like I remember, my memory goes back [to the genocide]. And then I feel I don't want to study. Sometimes I say, oh, why do I have to study?

It is important to know the circumstances of youth prior to their arrival in order to understand what they may need. Some youth may seem to be functioning well on the outside but on the inside, they may have a lot of repressed emotions and feeling. Experiences lived are not forgotten.

Youth spoke of being viewed primarily as "immigrants". According to youth, this broad category was void of meaning and did not allow peers and teachers to connect with the individual experience and needs.

Because for sure at school you are seen as an immigrant. That is where I see the difference between an « immigrant » and a «person », what you lived personally. You are seen as an immigrant, you're always asked the same question: "Where do you come from?, all that. And no one goes further than that. Not any further...they don't feel attached to you. You don't have enough connection. (Iris).

Youth spoke of feeling confused, showing signs of re-traumatisation and feeling the need to isolate from peers.

(What do you think might help youth having experienced war?) For the profs to be more...to pay more attention, or for them to know more. Because in my French class, there is also a girl from Rwanda. And the prof said, "We're going to the cinema to watch a Québécois film." And the film talked about the genocide in Rwanda. And the girl cried through the whole film. And in fact there were no resources at that time to help her. Everyone felt bad, and yes, we listened and everything, but it wasn't great. And I'm sure that after, there was no follow-up, there was no one... she didn't meet with anyone. So that's it. The professors should really be informed about that... if they knew more (Alina).

Moreover, youth felt that staff members would often assume trauma and pathology when hearing youth's difficult stories rather than explore possibilities for resilience. A youth tells her story:

I make an appointment, the first, and I see the psychologist. I tell her my story and we cry and cry and cry. [Both of you?] Yes! ... I make another appointment, and we cry and cry. And I said, "Actually, this is exhausting, this therapy." I don't go back. I think, we met for an hour and a half to cry. So I just never went back.

There have been concerns that the extended, and at times limited, focus on language acquisition and cultural integration with Quebec schools may promote a monolithic view of migration (Audet, 2011; McAndrew, 2001) among 
those working with children. This could lead to a weakened understanding of the complexities of migration within educational settings through a "uniformisation of differences" (McAndrew, 2001).

We wonder whether this reduced psychosocial emphasis on integration-related stressors, combined with the omission of trauma and pre- and peri-migratory experiences, may paradoxically marginalize certain children, and render invisible the complexities inherent to their experiences of resettlement and integration. Some authors have suggested that many schools may be ill-prepared to address the cultural and experiential heterogeneity of immigrant and refugee children (Hek, 2005; Nwosu \& Barnes, 2014). This near-sighted psychosocial lens, and the absence of discussion around pivotal past experiences could inadvertently lead to misdiagnosing and misinterpreting behaviors or symptoms such as inattention, anxiety and aggressivity (Husain et al., 2008) as well as scholastic and linguistic difficulties, common among ethnic minorities (Adeponle, Thombs, Groleau, Jarvis, \& Kirmayer, 2012; Gong-Guy, Cravens, \& Patterson, 1991).

Within many informal discussions and conferences with service providers seeking cultural competency, the concerns are often organised around how to talk or not talk about refugee children's past. Resonances of post war trauma or pre migratory experiences may create anxiety in service providers who are worried of re-igniting traumatic memories for children and youth. Indeed, Kirmayer (2003) discusses the impacts of "failure of imagination," the inability to imagine the realities of refugees and the psychological and interpersonal processes that take place. This failure of imagination can ultimately perpetuate and amplify social marginalisation. Youth in Blanchet-Cohen \& Denov's (2015) study provided multiple examples of how their peers and teachers showed "failures of imagination" that could lead to highly delicate situations.

Many studies suggest that war experiences can be part of stories of resilience and strength (Betancourt \& Khan, 2008; Cortes \& Buchanan, 2007; Measham et al. 2014). Measham et al. (2014) suggest that we "work around trauma" rather than "on trauma" in order to recognise the experiences of children.

\subsection{Exploring inter-ministerial differences in approaches}

There seems to exist a certain divide in approaches between the Health and Social Services and the Ministry of Education. The divide is not between psychosocial versus trauma approaches, but rather in the goals and underlying philosophies of the action plans. The MSSS is oriented towards individual and family wellbeing whereas the MELS places citizenship and development of Quebec at the forefront. The differences in priorities and orientations are clearly related to necessary differences in mandates and roles within society and are not in any way incompatible. This having been said, one can question how these differences in mandates, roles and orientations may be articulated in practice, especially in a period where inter-professional, and inter-organisational approaches are being promoted as best practice. Indeed, considering that refugee populations do not tend to seek psychosocial consultations on their own (Murphy et al. 2002), and tend to favour services that are close in proximity to their living environment and everyday lives (Younes et al, 2005; Rousseau, Measham \& Nadeau, 2013), schools are viewed as a rich space for prevention and promotion of wellbeing (Ayalon, 1998; Guzder, 2011) as well as screening of potential difficulties and referral to specialised services (Hek, 2005). Hodes et al. (2008) suggests that schools could offer a variety of health and social services to refugee youth who may not be accessing third line services. Without placing the onus on schools, it is important that school staff be made aware of the experiences and challenges of children having experienced trauma in order to enhance screening of difficulties and linking with the appropriate services. Moreover, training can help support school staff think about small actions that can help children having been exposed to trauma in their integration and wellbeing without the need for specialised care. Indeed, school is the system in which children spend most of their time. Having a feeling of psychological safety within this environment is crucial. This means having the space to speak (or not speak) about one's experience without feeling judged and ostracised. In no way do we assume that this is the case within schools. However ministries may consider exploring the impact of trauma on integration and learning.

Sirois (2011) offers a guide for schools working with children having been exposed to war. She offers activities that can be done with children to explore their migration history, difficult experiences, their integration, and basic coping skills. The clinical research "Erit team" headed by Cecile Rousseau has developed innovative creative expression workshops implemented within schools to help teachers and youth work with experiences of trauma, migration and integration (Rousseau, 2003; Measham, Rousseau \& Nadeau, 2005). Moreover, specialised mental health services for refugee children encourage community-oriented and family approaches where school staff and community organisations are seen as partners in care (Kirmayer, Jarvis \& Guzder, 2014; Measham et al., 2014; Nadeau et al, 2005; Nadeau, Rousseau \& Measham, 2014; Rousseau, Measham \& Nadeau, 2013). This requires complex inter-professional and inter-institutional practices that are generally not part of professional training and not always easily implemented due to clinical, organisational and administrative barriers. Greater integration of ministerial policies may enhance these collaborations by defining protocols for working together however it requires a common understanding of children's 
needs.

\section{Conclusion}

This paper has attempted to outline both current Quebec policies with regard to support and services to war-affected children and adolescents and the policy premises regarding needs of refugee children entering the province. Experiences of war do not necessarily translate into specific trauma sequelae but rather, have multiple complex trajectories including a spectrum of resilient outcomes with many children having good outcomes. The post migration circumstances of the host society as well as the generational psychic impact of war experiences are dynamic elements for each child's developmental trajectory, identity formation and internalized history, which are fundamental to wellbeing and social identities. While our literature review suggests a bias in favour of promoting integration of trauma-oriented and psychosocial oriented models to address the complex needs of refugee children, we find that Quebec policies are primarily psychosocial in their orientation. The MSSS and other ministries dealing with children also present divergences in their respective approaches, divergences that may very well be due to differences in mandates. The MICC, MELS and recent MFA policies are clearly integration oriented and centered on the acquisition of the French language and general scholastic success. French language fluency of newcomers is one of the tools essential for wellbeing and assimilation processes, however it may be necessary to expand the focus to include other important factors and impingements on child development for survivors of war, organized violence and trauma.

Since the current Quebec policy impacts the training and orientation for key service providers for systems of care accessed through schools, health institutions and related organizations, we suggest best practices might be promoted with a working framework that acknowledges both social and psychological dimensions of care. For instance, exposure of service providers to basic trauma and developmental practices relevant to families and children who have experienced conflict and violence may be significant to helping these families. Sensitizing teachers and health workers to pre-migratory trauma effects on children, combined with interventions aimed at strengthening social connections in the community and family have yielded positive results (Ager, 2006; Boyden, 1994; Kos \& Zemljak 2007). As war-affected children are increasingly making their way to Quebec, especially in the current socio-political context where Quebec and Canada are in the process of welcoming thousands of Syrian refugee families, there is an urgency to develop appropriate services and social policy responses.

We suggest that a review of gaps in best practices in policy could lead to positive policy changes to influence outcomes for Quebec children facing integration barriers, higher drop out rates than host culture children or social and school difficulties. Different ministries have already recognised the limitations of current services for refugees and have highlighted the importance of reassessing the current services for refugees, especially as erosion of current federal funding has impacted basic health and social services of asylum seekers. In light of these budgetary cuts, the provincial government has made efforts towards enhancing services. Until 2015, the expansion of services and action plans have been primarily elaborated from the perspective of schooling and institutional care, largely ignoring input on the needs and experiences of the service users and their possible contribution to shaping policies and guidelines. Since the dynamics of Quebec's identity and assimilation legacy are complex, participatory approaches on policy development might benefit from policy makers engaging with the potential agency and voices of youth and minority communities who have endured war and conflict region experience.

From our review of the literature we propose Miller and Rasmussen's (2010; 2016) integrative model as a benchmark for a comprehensive understanding of children's realities and needs. This model acknowledges the pre, peri and post migratory experiences of children and addresses both traumatic experiences and psychosocial realities of children as they interact. A vast amount of literature also points to the need for systemic, family-oriented and community-based approaches are more successful in meeting the needs of children having been exposed to war.

Quebec has leading researchers, clinicians and services in transcultural psychiatry mostly located in Montreal. Specialized services include CSSS de la Montagne's Equipe de Recherche et d'Intervention Transculturelle Team ${\text { (ERIT })^{6} \text {, PRAIDA }}^{7}$, CSSS Coeur de l'ile ${ }^{8}$, Maisonneuve-Rosemont's transcultural pediatric clinic ${ }^{9}$, the Cultural Consultations Service ${ }^{10}$, RIVO ${ }^{11}$, and multiple minority community partners. These various services and organizations have actively pursued approaches that integrate trauma and psychosocial models (similar to that of Miller and

\footnotetext{
${ }^{6}$ More information at www.sherpa-recherche.com/fr/sherpa/equipes-recherche/erit/

${ }^{7}$ More information at www.cic.qc.ca/francais/ministere/partenariat/pese/praida.asp

${ }^{8}$ More information at www.cssscoeurdelile.ca/soins-et-services/pour-tous/sante-mentale/clinique-de-psychiatrie-transculturelle

9 More information at www.maisonneuve-rosemont.org/pages/H/DeparmentsEtServices/clinique pediatriquetransculturelle.aspx?lang=FR-CA

${ }_{10}$ More information at mcgill.ca/culturalconsultation/

11 More information at www.rivo-resilience.org
} 
Rasmussen) to meet the diverse psychosocial needs of refugees. These service provider teams have emphasized that culturally safe and competent care has to acknowledge the heterogeneity and uniqueness of individual immigrant families and individual members within these families. Quebec policies may move to address institutional approaches that acknowledge both the special social realities of the province as well as the psychological dynamics, the strengths and the challenges experienced by war survivors. Taking such action, Quebec policy for war-affected youth has the potential to set precedence not only for all Canadian provinces, but for other Global North countries who resettle refugee children.

\section{References}

Adeponle, A. B., Thombs, B. D., Groleau, D., Jarvis, E., \& Kirmayer, L. J. (2012). Using the cultural formulation to resolve uncertainty in diagnoses of psychosis among ethnoculturally diverse patients. Psychiatric Services, 63(2), 147-153. http://dx.doi.org/ 10.1176/appi.ps.201100280

Ager, A. (2006). What is family? The nature and functions of families in times of conflict. A world turned upside down: Social ecological approaches to children in war zones. Bloomfield, CT: Kumarian Press, Inc.

Akello, G., Richters, A., \& Reis, R. (2006). Reintegration of former child soldiers in northern Uganda : Coming to terms with children's agency and accountability. Intervention, 4(3), 229-243.

Akesson, B., D’Amico, M., Denov, M., Khan, F., Linds, W., \& Mitchell, C. A. (2014). 'Stepping back' as researchers : Adressing ethics in arts-based approaches to working with war-affected children in school and community settings. Educational Research for Social Change (ERSC), 3(1), 75-89.

Audet, G. (2011). Interculturelle en classe: Pour une prise en compte de la spécificité culturelle dans l'intervention. Revue des Sciences de l'Éducation de McGill, 46(3), 443-458.

Ayalon, O. (1998). Community healing for children traumatized by war. International Review of Psychiatry, 10, 224-233. http://dx.doi.org/ 10.1080/09540269874817

Ayalon, O. (1998). Community healing for children traumatized by war. International Review of Psychiatry, 10, 224-233.

Bates, L., Baird, D., Johnson, D. J., Lee, R. E., Luster, T., \& Rehagen, C. (2005). Sudanese refugee youth in foster care: the" lost boys" in America. Child Welfare: Journal of Policy, Practice, and Program, 84(5), 631-48.

Betancourt, T. S., \& Khan, K. T. (2008). The mental health of children affected by armed conflict: protective processes and pathways to resilience. International Review of Psychiatry, 20(3), 317-328. http://dx.doi.org/ $10.1080 / 09540260802090363$

Betancourt, T. S., \& Williams, T. (2008). Building an evidence base on mental health interventions for children affected by armed conflict. intervention (amstelveen, netherlands), 6(1), 39 .

http://dx.doi.org/10.1097/wtf.0b013e3282f761ff

Betancourt, T. S., Agnew-Blais, J., Gilman, S. E., Williams, D. R., \& Ellis, B. H. (2010). Past horrors, present struggles: The role of stigma in the association between war experiences and psychosocial adjustment among former child soldiers in Sierra Leone. Social Science \& Medicine, 70(1), 17-26.

Blanchet-Cohen, N., \& Denov, M. (2015). War-affected children's approach to resettlement : Implications for child and family services. Annals of Anthropological Practice, 39(2), 120-133.

Boothby, N., Strang, A., \& Wessels, M. G. (2006). A world turned upside down: Social ecological approaches to children in war zones. Bloomfield, CT: Kumarian Press, Inc.

Boyden, J. (1994). Children's experience of conflict related emergencies: Some implications for relief policy and practice. Disasters, 18, 254-267.

Burnett, A., \& Peel, M. (2001). Health needs of asylum seekers and refugees. British Medical Journal, 322(7285), 544-547.

Cortes, L., \& Buchanan, M. J. (2007). The experience of Columbian child soldiers from a resilience perspective. International Journal for the Advancement of Counselling, 29(1), 43-55. http://dx.doi.org/10.1007/s10447-006-9027-0

Daiute, C. (2008). The rights of children, the rights of nation: Developmental theory and the politics of children's rights. Journal of Social Issues, 64(4), 701-723. http://dx.doi.org/10.1111/j.1540-4560.2008.00585.x

Denov, M., \& Akesson, B. (2013). Neither here nor there? Place and placemaking in the lives of separated children. International Journal of Migration, Health and Social Care, 9(2), 56-70. 
http://dx.doi.org/10.1108/IJMHSC-06-2013-0012

Denov, M., \& Blanchette-Cohen, N. (2014). The rights and realities of war-affected refugee children and youth in Quebec: Making children's rights meaningful. Canadian Journal of Children's Rights, 1(1), 18-43.

Denov, M., \& Bryan, C. (2014). Social Navigation and Resettlement: Separated Children in the Context of Canada. Refuge: Canada's Periodical on Refugees, 30(1), 25-34.

Denov, M., \& Bryan, C. (2012). Tactical maneuvering and calculated risks: Independent child migrants and the complex terrain of flight. New Directions for Child and Adolescent Development, 136, 13-27. http://dx.doi.org/10.1002/cad.20008.

Derluyn, I., \& Broekaert, E. (2007). Different perspectives on emotional and behavioural problems in unaccompanied refugee children and adolescents. Ethnicity and Health, 12(2), 141-162.

Ellis, B. H., MacDonald, H. Z., Lincoln, A. K., \& Cabral, H.J. (2008). Mental health of Somali adolescent refugees: the role of trauma, stress, and perceived discrimination. Journal of consulting and clinical psychology, 76(2), 184. http://dx.doi.org/ 10.1037/0022-006X.76.2.184.

Ertl, V., Pfeiffer, A., Schauer, E., Elbert, T., \& Neuner, F. (2011). Community-implemented trauma therapy for former child soldiers in Northern Uganda. JAMA, 306(5), 503-512. http://dx.doi.org/ 10.1001/jama.2011.1060.

Fantino, A. M., \& Colak, A. (2001). Refugee children in Canada: Searching for identity. Child Welfare New York, 80(5), 587-596.

Fazel, M., Reed, R.V., Panter-Brick, C., \& Stein, A. (2012). Mental health of displaced and refugee children resettled in high-income countries: risk and protective factors. The Lancet, 379(9812), 266-282. http://dx.doi.org/10.1016/S0140-6736(11)60051-2

Fontaine, L. (1993). L'organisation étatique des citoyens "ethniques" au Québec. Études Canadiennes, 34, 55-65.

Gong-Guy, E., Cravens, R. B., \& Patterson, T.E. (1991). Clinical issues in mental health service delivery to refugees. American Psychologist, 46(6), 642.

Gorst-Unsworth, C., \& Goldenberg, E. (1998). Psychological sequelae of torture and organised violence suffered by refugees from Iraq. Trauma-related factors compared with social factors in exile. The British Journal of Psychiatry, 172(1), 90-94.

Greenwald, R. (2000). A trauma-focused individual therapy approach for adolescents with conduct disorder. International Journal of Offender Therapy and Comparative Criminology, 44(2), 146-163. http://dx.doi.org/10.1177/0306624X00442002

Guyon, S. (2011). The resettlement of refugees selected abroad in Quebec, a well kept secret! In INSCAN. L'établissement international au Canada, 24(3-4), 16-18.

Guzder, J. (2011). Children as the symptom bearers: Supporting South Asian families through school interventions. Comparative and International Education, 40(2), 110-123.

Hek, R. (2005). The role of education in the settlement of young refugees in the UK: The experiences of young refugees. Practice, 17(3), 157-171. Http://dx.doi.org/ 10.1080/09503150500285115

Helly, D. (1996). Le Québec face à la pluralité culturelle, 1977-1994: un bilan documentaire des politiques, 36. Sainte-Foy, Québec: Institut québécois de recherche sur la culture.

Hodes, M., Jagdev, D., Chandra, N., \& Cunniff, A. (2008). Risk and resilience for psychological distress amongst unaccompanied asylum seeking adolescents. Journal of Child Psychology and Psychiatry. 49. 723-32. Http://dx.doi.org/ 10.1111/j.1469-7610.2008.01912.x

Husain, S. A., Allwood, M. A., \& Bell, D. J. (2008). The relationship between PTSD symptoms and attention problems in children exposed to the Bosnian war. Journal of Emotional and Behavioral Disorders, 16(1), 52-62. Http://dx.doi.org/ 10.1177/1063426607310847

Kirmayer, L. J. (2003). Failures of imagination: The refugee's narrative in psychiatry. Anthropology \& medicine, 10(2), 167-185. Http://dx.doi.org/ 10.1080/1364847032000122843

Kirmayer, L. J., Jarvis, G. E., \& Guzder, J. (2014). The process of cultural consultation. In Cultural Consultation, 47-69. Springer New York.

Kirmayer, L. J., Narasiah, L., Munoz, M., Rashid, M., Ryder, A. G., Guzder, J., ... \& Pottie, K. (2011). Common mental health problems in immigrants and refugees: general approach in primary care. Canadian Medical Association 
Journal, 183(12), 959-967. Http://dx.doi.org/10.1503/cmaj.090292

Kohrt, B. A., Jordans, M. J. D, Tol, W. A., Perera, E., Karki, R., Koirala, S., \& Upadhaya, N. (2010) Social ecology of child soldiers: Child, family and community determinants of mental health, psychosocial well-being and reintegration in Nepal. Transcultural Psychiatry, 47(5), 727-753. http://dx.doi.org/ 10.1177/1363461510381290

Kos, A. M., \& Zemljak, B. (2007). Psychosocial support for children, families and teachers in Iraq. Intervention, 5, $150-158$.

Macksoud, M., Dyregrov, A., \& Raundalen, M. (1993). Traumatic war experiences and their effects on children. In J. Wilson \& B. Raphael (Eds.), International handbook of traumatic stress syndromes, 625-633

Mc-Andrew, M. (2001). Immigration et diversité à l'école. Le débat québécois dans une perspective comparative. Montréal : Presses de l'Université de Montréal.

Measham, T., Guzder, J., Rousseau, C., Pacione, L., Blais-McPherson, M., \& Nadeau, L. (2014). Refugee children and their families : Supporting psychological wellbeing and positive adaptation following migration. Current Problems Pediatric Adolescent Health Care, 44, 208-215. http://dx.doi.org/ 10.1016/j.cppeds.2014.03.005.

Measham, T., Rousseau, C., \& Nadeau, L. (2005). The development and therapeutic modalities of a transcultural child psychiatry service. The Canadian child and adolescent psychiatry review, 14(3), 68.

Medeiros, E. (2007). Integrating mental health into post-conflict rehabilitation: The case of sierra Leonean and Liberian "Child Soldiers". Journal of Health Psychology, 12(3), 498-504.

Miller, K. E., \& Rasmussen, A. (2016). The mental health of civilians displaced by armed conflict: an ecological model of refugee distress. Epidemiological and Psychiatric Sciences, 4, 1-10. http://dx.doi:10.1017/S2045796016000172.

Miller, K. E., \& Rasmussen, A. (2010). War exposure, daily stressors, and mental health in conflict and post-conflict settings: bridging the divide between trauma-focused and psychosocial frameworks. Social Science \& Medicine. 70(1), 7-16. http://dx.doi.org/ 10.1016/j.socscimed.2009.09.029.

Miller, K. E., Weine, S., Ramix, A., Brkic, N., Bjedic, Z. D., Smajkic, A., Boskailo, E., \& Worthington, G. (2002). The relative contribution of war experiences and exile-related stressors to levels of psychological distress among Bosnian refugees. Journal of Traumatic Stress, 15(5), 377-387. http://dx.doi.org/10.1023/A:1020181124118

Ministère de l'Éducation, du Loisir et du Sport. (2014). Cadre de reference Accueil et integration des élèves issus de l'immigration au Québec. Québec.

Ministère de l'Immigration et des Communautés Culturelles 2013-2016 (2015). Plan d'action du gouvernement du Québec pour l'accueil et l'intégration des personnes réfugiées sélectionnées à l'étranger. Gouvernement du Québec. Retrieved on October 4th 2015 at :

https://www.immigration-quebec.gouv.qc.ca/publications/fr/divers/PLA_AccueilRefugies2013-2016.pdf

Ministère de l'Immigration et des Communautés Culturelles. (2009). Présence en 2009 des immigrants admis au Québec de 1998 à 2007.Gouvernement du Québec.

Ministère de la Famille. (2013). La diversité: Une valeur ajoutée Guide pour l'élaboration d'une politique d'immigration des enfants de nouveaux arrivants et de gestion de la diversité dans les services de garde éducatifs. Pour favoriser la participation de tous à l'essor du Québec. Gouvernement du Québec.

Ministère de la Santé et des Services Sociaux. (2012). Une passerelle vers un avenir en santé. La planification et l'organisation des services à l'intention des réfugiés et des demandeurs d'asile: évaluer le bien-être et l'état de santé physique pour mieux desservir. Québec.

Murphy, D., Ndegwa, D., Kanani, A., Rojas-Jaimes, C., \& Webster, A. (2002). Mental health of refugees in inner-London. BJPsych Bulletin, 26(6). http://dx.doi.org/10.1192/pb.26.6.222

Nadeau, L., \& Measham, T. (2005). Immigrants and mental health services: Increasing collaboration with other service providers. The Canadian child and adolescent psychiatry review, 14(3), 73.

Nadeau, L., Rousseau, C., \& Measham, T. (2014). Addressing cultural diversity through collaborative care. In Cultural Consultation, Springer New York, 203-221.

Nwosu, O. C., \& Barnes, S. L. (2014). Where 'difference is the norm': Exploring refugee student ethnic identity development, acculturation, and agency at shaw academy. Journal of Refugee Studies, 27(3), 434-456. http://dx.doi.org/10.1093/jrs/fet050

Pacione, L., Measham, T., \& Rousseau, C. (2013). Refugee children: Mental health and effective interventions. Current Psychiatry Reports, 15(2), 1-9. http://dx.doi.org/10.1007/s11920-012-0341-4 
Poynting, S., \& Mason, V. (2007). The resistable rise of Islamophobia Anti-Muslim racism in the UK and Australia before and after September 2001. Journal of Sociology, 43(1), 61-86. http://dx.doi.org/10.1177/1440783307073935

Québec, Secrétariat à la famille. Familes en tete, 1995-1997 plan d'action des partenaires en matière familiale / Gouvernement du Québec, Secrétariat à la famille.

Rousseau, C. (1995). The mental health of refugee children. Transcultural Psychiatry, 32(3), 299-331.

Rousseau, C., Jamil, U., Bhui, K., \& Boudjarane, M. (2015). Consequences of 9/11 and the war on terror on children's and young adult's mental health: A systematic review of the past 10 years. Journal of Clinical Child Psychology and Psychiatry, 20(2), 173-193.

Rousseau, C., Lacroix, L., Bagilishya, D., \& Heusch, N. (2003). Working with myths: Creative expression workshops for Immigrant and Refugee children in a school setting. Art Therapy: Journal of American Art Therapy Association, 20(1), 3-10. http://dx.doi.org/ 10.1080/07421656.2003.10129630

Rousseau, C., Measham, T., \& Nadeau, L. (2013) Addressing trauma in collaborative mental health care for refugee children. Clinical child psychology and psychiatry, 18(1), 121-136. http://dx.doi.org/ 10.1177/1359104512444117.

Rousseau, C., Nadeau, L., \& Measham, T. (2013). Addressing trauma in collaborative mental health care for refugee children. Clinical Child Psychology and Psychiatry, 18(1), 121-136.http://dx.doi.org/ 10.1177/1359104512444117.

Salée, D. (2007). The Quebec state and the management of cultural diversity: Perspectives on an ambiguous record. In K. Banting, T. Courchene \& L. Seidle (Eds.), Belonging? Diversity, recognition and shared citizenship in Canada, Montréal: Institute for Research on Public Policy, 105-142.

Schweitzer, R. D., Brough, M., Vromans, L., \& Asic-Kobe, M. (2011). Mental health of Newly arrived Burmese refugees in Australia: contributions of pre-migration and post-migration experience. Australian and New Zealand Journal of Psychiatry, 45(4), 299-307. http://dx.doi.org/ 10.3109/00048674.2010.543412

Sirois, N. (2011). Ton étoile du Nord . Cahier destine aux jeunes ayant vécu la guerre ou des moments de grande violence sociale avant de frequenter une école au Canada. Ottawa, Ont. : Centre ontarien de prévention des agressions (COPA). ISBN : 9780987836809

Somasundaram, D. J. (1996). Post-traumatic responses to aerial bombing. Social Science \& Medicine, 42(11), 1465-1471.

Steel, Z., Silove, D., Bird, K., McGorry, P., \& Mohan, P. (1999). Pathways from war trauma to posttraumatic stress symptoms among Tamil asylum seekers, refugees, and immigrants. Journal of traumatic stress, 12(3), 421-435. http://dx.doi.org/10.1023/A:1024710902534

Stewart, J. (2011). Supporting refugee children: Strategies for educators. Toronto: U of Toronto Press.

Thabet, A. A. M., \& Vostanis, P. (1999). Post-traumatic stress reactions in children of war. Journal of child Psychology and Psychiatry, 40(3), 385-391.

Thabet, A. A. M., Karim, K., \& Vostanis, P. (2006). Trauma exposure in pre-school children in a war zone. The British Journal of Psychiatry, 188(2), 154-158.

Thompson, C. B. (1999). Beyond civil society: Child soldiers as citizens in Mozambique. Review of African Political Economy, 26(80), 191-206.

UNICEF. (2009). Machel Study 10-year Strategic Review: Children and Conflict in a Changing World.

United Nations. (2010). The rights and guarantees of internally displaced children in armed conflict. NY: UN.

Vengroff, R. (2013). Immigration policy at the subnational level in North America: Quebec and Georgia in comparative Perspective. Norteamérica, 8, 141-170.

Vizek-Vidović, V., Kuterovac-Jagodić, G. \& Arambašić, L. (2000). Posttraumatic symptomatology in children exposed to war. Scandinavian Journal of Psychology, 41(4), 297-306. Http://dx.doi.org/10.1111/1467-9450.00202

Younes, N., Gasquet, I., Gaudebout, P., Chaillet, M-P., Kovess, V., Falissard, B. \& Hardy Bayle, M-C. (2005). General practitioners' opinions on their practice in mental health and their collaboration with mental health professionals. BMC Family Practice, 6(1), 18-24.

\section{$(\mathrm{cc}) \mathrm{BY}$}

This work is licensed under a Creative Commons Attribution 3.0 License. 